\title{
Assessment of the Effective Impact of Bisphenols on Mitochondrial Activity, Viability and Steroidogenesis in a Dose-Dependency in Human Adrenocortical Carcinoma Cells
}

\author{
Nikola Knížatová ${ }^{1, * \mathbb{D}}$, Hana Greifová ${ }^{1}$, Katarína Tokárová ${ }^{1} \mathbb{D}$, Tomáš Jambor ${ }^{2}$, Lukasz J. Binkowski $^{3}$ \\ and Norbert Lukáč 1
}

1 Department of Animal Physiology, Faculty of Biotechnology and Food Sciences, Slovak University of Agriculture in Nitra, Tr. A. Hlinku 2, 94976 Nitra, Slovakia; hana.greifova@uniag.sk (H.G.); katarina.tokarova@uniag.sk (K.T.); norbert.lukac@uniag.sk (N.L.)

2 BioFood Centre, Faculty of Biotechnology and Food Sciences, Slovak University of Agriculture in Nitra, Tr. A. Hlinku 2, 94976 Nitra, Slovakia; tomas.jambor@uniag.sk

3 Faculty of Exact and Natural Sciences, Institute of Biology, Pedagogical University of Cracow, Podchorą̇̇ych 2, 30-084 Kraków, Poland; lukasz.binkowski@up.krakow.pl

* Correspondence: nikola.knizatova@gmail.com or xknizatovan@uniag.sk; Tel.: +421-37-641-4288

Citation: Knížatová, N.; Greifová, H.; Tokárová, K.; Jambor, T.; Binkowski, Ł.J.; Lukáč, N. Assessment of the Effective Impact of Bisphenols on Mitochondrial Activity, Viability and Steroidogenesis in a

Dose-Dependency in Human Adrenocortical Carcinoma Cells. Processes 2021, 9, 1471. https:// doi.org/10.3390/pr9081471

Received: 22 July 2021

Accepted: 19 August 2021

Published: 23 August 2021

Publisher's Note: MDPI stays neutral with regard to jurisdictional claims in published maps and institutional affiliations.

Copyright: (c) 2021 by the authors. Licensee MDPI, Basel, Switzerland. This article is an open access article distributed under the terms and conditions of the Creative Commons Attribution (CC BY) license (https:// creativecommons.org/licenses/by/ $4.0 /)$.

\begin{abstract}
In recent years, bisphenol analogues such as bisphenol B (BPB), bisphenol F (BPF), and bisphenol S (BPS) have come to replace bisphenol A (BPA) in food packaging and food containers, since BPA has been shown to leach into food and water, causing numerous negative health effects. Although much information on the endocrine activity of BPA is available, a proper human hazard assessment of analogues that are believed to have a less harmful toxicity profile is lacking. The aim of our in vitro study was to assess the potential effect of bisphenol B, F, and S on the biosynthesis of steroid hormones in human H295R adrenocortical carcinoma cells, using the enzyme-linked immunosorbent assay. In addition, we evaluated mitochondrial activity using the MTT test and viability using triple assay. Adrenocortical carcinoma cells were cultivated for $24 \mathrm{~h}$ in the presence of bisphenol B, F, or S $(0.1,0.5,1,10,25,50,75,100 \mu \mathrm{M})$. We demonstrated that BPB, BPF, and BPS could affect progesterone and testosterone secretion, as well as affect cell mitochondrial, lysosomal, and metabolic activity, as well as plasma membrane integrity, but considerably more detailed and systematic research is required for a better understanding of risks associated with the effects of bisphenols on steroidogenesis.
\end{abstract}

Keywords: adrenocortical carcinoma cells; H295R; viability; mitochondrial activity; steroidogenesis; testosterone; progesterone

\section{Introduction}

The growing global production and release of industrial chemicals into the environment have prompted scientists to speculate that current pollutants such as bisphenols may unquestionably disrupt health conditions, resulting in extensive physiological function damage via endocrine disruption [1,2]. Bisphenols (BPs) have been used all over the world for decades. Bisphenol compounds can be found in plastics used by consumers for food storage, baby formula packaging, baby bottles, the lining of canned food and drink cans, dental implants, and sales receipts [3].

The first indications about the possible leakage of bisphenol monomers into food and drink were published in 2007. BPA (bisphenol A) has since become one of the most well-known EDCs (endocrine-disrupting chemicals) because of its strong effects on steroid hormone production [2,4-8], disturbed mammary gland development [9], changes in obesity-associated parameters [10], reproductive and developmental toxicity [11], heart disease, diabetes, abnormal liver function [12-14], and the nervous system [15,16]. The significant majority of the population is exposed to BPA, according to Zhang et al. (2011) 
and Calafat et al. (2008) [5,17]. Diet is estimated as the main source of human exposure, followed by thermal paper [18]. Generally speaking, humans consume less than $1 \mathrm{~g} / \mathrm{kg}$ body weight per day of BPA, although occupationally exposed individuals had considerably greater BPA levels in the blood than those exposed to BPA in the environment $[19,20]$. According to studies from numerous countries and on people of various ages, the quantity of BPA in human blood varies from 0.2 to $20 \mathrm{ng} / \mathrm{mL}(0.0008-0.088 \mu \mathrm{M})$ [12]. BPA levels in the urine of Chinese males working in facilities making semiautomatic epoxy resin have been reported to reach $1934.85 \mathrm{ng} / \mathrm{mL}$, which corresponds to experimental dosages of $8.41 \mu \mathrm{M}$ [21]. Heinälä et al. (2017) report BPA levels reaching $1273 \mathrm{ng} / \mathrm{mL}$ in workers in Finland working at plants manufacturing thermal paper. This value corresponds to experimental dosages of $5.55 \mu \mathrm{M}$ [22].

As BPA is being removed from consumer items, there is a progressive move to its analogues, bisphenols $\mathrm{B}, \mathrm{F}$, and $\mathrm{S}$, as polycarbonate resin components are occurring [23]. The industry quickly formulated new BPA-free plastics, which were made using bisphenol analogs with highly similar structure and chemical properties to be used in packing and storage containers for food instead of BPA as a result of a ban on BPA-containing products for babies in the EU, and guidelines to avoid using BPA for baby bottles and formula packaging in the US. Bisphenols are fabricated by combining phenol with acetone (BPA), 2-butanone (BPB), formaldehyde (BPF), or sulfur trioxide (BPS). The recent monomer, BPS, is the most common BPA analog marketed in BPA-free products [24-26]. BPB, BPF, and BFS can be found in canned soft beverages and foods, as well as thermal receipt paper [27-30]. BPA has the highest concentration in food items, followed by BPF, BPS, and BPB [30]

Previous research has found that direct inhibition of BPA analogs on steroidogenesis and hormonal imbalance is extensively discussed. Additionally, BPA substitutes have been shown to have neurotoxicity, genotoxicity, reproductive toxicity, and significant endocrinedisrupting effects, according to several studies [2,30-33]. Furthermore, BPS has been found in human urine samples [34]. Eladak et al. (2015) observed that rat and mouse fetal testes are at least 100 times less sensitive to BPA than human fetal testes. They demonstrated that in basal conditions, BPS and BPF, which are gradually replacing BPA, have antiandrogenic effects similar to the antiandrogenic properties that are comparable to BPA's [35].

Sexual steroid hormones are important regulators of reproduction in vertebrates, and they also play a role in a variety of other developmental and growth processes. As a result, substances that alter steroid hormone synthesis may be directly related to adverse outcomes for these processes [36,37]. Toxicological data are currently limited, and experimental research evaluating BPA analogue effects is unclear. As a result, we decided to investigate the effects of BPB, BPS, and BPF on cellular toxicity and possible steroidogenesis-disrupting activity in vitro.

Cell lines are an excellent biological model for investigating the direct impact of various chemical and physical variables on steroidogenesis, H295R cells are a useful tool for detecting hazardous substances that interfere with steroidogenesis [38-40]. The test guideline of the H295R steroidogenesis assay (TG 456) was verified by the Organization for Economic Cooperation and Development [41]. The human adrenocortical cancer cell line NCI-H295R was used as a model system for detecting the effects of BPB, BPS, and BPF on the secretion of sex steroid hormones (testosterone, progesterone) in vitro in the current study. $\mathrm{H} 295$ cells used to establish this cell line were obtained from a primary hormonally active adrenocortical carcinoma [38,39].

The objective of our study was to determine the effects of bisphenol B, F, and S on the steroidogenesis of the human adrenocortical carcinoma cell line (NCI-H295R). Specifically, we examined the dose-dependent changes of bisphenols as endocrine disruptors concerning the production of progesterone and testosterone by adrenocortical carcinoma cells in vitro. Quantification of steroid hormones was performed using the enzyme-linked immunosorbent assay (ELISA). In addition, we evaluated mitochondrial activity (using the MTT test) and cell viability parameters (using the triple test). 


\section{Materials and Methods}

\subsection{H295R Cell Culture and Treatment}

The American Type Culture Collections provided the NCI-H295R cells (ATCC CRL2128; ATCC, Manassas, VA, USA). The cells were cultured using protocols that had previously been established and validated. After starting the H295R culture from the ATCC batch, the cells were cultured for four passages before being split and frozen in liquid nitrogen. To obtain optimum hormone synthesis, the cells used in the following experiments were cultured for a minimum of three more passages. The H295R cells were grown in $25 \mathrm{~cm}^{2}$ plastic tissue culture flasks (TPP, Trasadingen, Switzerland) in Dulbecco's Modified Eagle Medium/Nutrient F-12 Ham 1:1 mixture (Sigma, St. Louis, MO, USA) supplemented with $1.2 \mathrm{~g} / \mathrm{L} \mathrm{NaHCO}_{3}$ (Molar Chemicals Halasztelek, Hungary), $12.5 \mathrm{~mL} / \mathrm{L}$ of BD NuSerum (BD Bioscience, Bath, UK), and $5 \mathrm{~mL} / \mathrm{L}$ of ITSC Premix (Corning, AZ, USA) in a $\mathrm{CO}_{2}$ incubator at $37^{\circ} \mathrm{C}$ with a $5 \% \mathrm{CO}_{2}$ atmosphere. The culture medium was changed four times per week, and it was removed from the culture flasks once an acceptable cell density had been achieved. With $0.25 \%$ trypsin-EDTA (Sigma-Aldrich, St. Louis, MO, USA) for $4 \mathrm{~min}$, the H295R cells were detached from the bottom of the $25 \mathrm{~cm}^{2}$ culture flasks. The cells were then centrifuged for $5 \mathrm{~min}$ at $125 \times g$ before being resuspended in a fresh cell culture medium. A hemocytometer (Burker chamber) was used to count the cells and adjust the concentration to the required level. The cell suspension was plated into sterile 96-well cell culture plates $(60,000$ cells $/ 100 \mu \mathrm{L} /$ well) for cytotoxicity and hormone measurements. The cells were incubated for $24 \mathrm{~h}$ in a $\mathrm{CO}_{2}$ incubator at $37^{\circ} \mathrm{C}$ under a humidified atmosphere of $95 \%$ air and $5 \% \mathrm{CO}_{2}$. To explore the effect of bisphenols, cells were cultured for $24 \mathrm{~h}$ in a medium containing specific concentrations of each bisphenol $(0.1,0.5,1,10,25,50$, 75, $100 \mu \mathrm{M}$; Sigma-Aldrich, St. Louis, MO, USA). Cells without any treatment served as a control group; DMSO $(0.1 \%)$ served as a negative control. The specific concentration range of bisphenols was chosen based on the findings of our pilot range-finding studies. Each experiment was repeated 3 times with cells from different passages each time.

\subsection{Mitochondrial Activity Assay}

The MTT (3-4,5-dimetyltiazol-2-yl)-2,5-diphenyltetrazolium bromide) (NR; SigmaAldrich, St. Louis, MO, USA) the test was used to evaluate the mitochondrial activity of adrenocortical carcinoma cells exposed to various concentrations of bisphenol B, F, and S. The reduction in a yellow tetrazolium salt to insoluble blue formazan in the mitochondria of live cells was measured in this assay [42]. After $24 \mathrm{~h}$ of treatment, cells were incubated in a $\mathrm{CO}_{2}$ incubator for $1 \mathrm{~h}$ with MTT tetrazolium salt (Sigma-Aldrich, St. Louis, MO, USA). The supernatants were then removed, and the formed formazan crystals were dissolved with isopropanol (p.a. CentralChem, Bratislava, Slovak Republic). An ELISA reader (Multi-scan FC, ThermoFisher Scientific, Vantaa, Finland) was used to measure dissolved formazan at $570 \mathrm{~nm}$ against $620 \mathrm{~nm}$ wavelengths. All of the data were expressed as a percentage of the control group.

\subsection{Triple Assay}

Three cellular activities were monitored for cell viability using three different indicator dyes were used: metabolic activity with alamarBlue (ThermoFisher Scientific, Waltham, MA, USA), plasma membrane integrity with 5-carboxyfluorescein diacetate acetoxymethyl ester (CFDA-AM; ThermoFisher Scientific, Waltham, MA, USA), and lysosomal activity with neutral red (NR; Sigma-Aldrich, Waltham, MA, USA). The resazurin reduction test is also known as the AlamarBlue assay. Resazurin is a nontoxic, cell-permeable, blue nonfluorescent redox indicator that may be used to measure the number of live cells by measuring the quantity of resorufin-to-resorufin conversions by mitochondrial and other enzymes, such as diaphorases. When resazurin enters cells, it is converted to resorufin, a red, highly fluorescent color. Viable cells convert resazurin to resofurin continually, enhancing the fluorescence of the culture medium. A microplate reader fluorometer can be used to measure the ratio of cell metabolic activity. Another fluorogenic dye that indicates plasma 
membrane integrity is CFDA-AM. It is a nontoxic esterase substrate that can be metabolized by nonspecific esterases in live cells from a membrane-permeable, nonpolar, nonfluorescent material to polar, fluorescent carboxyfluorescein (CF). This conversion indicates the plasma membrane's integrity, as only an intact membrane can sustain the cytoplasmic milieu required for esterase activity. Neutral red staining belongs to the colorimetric assays. Nonionic passive diffusion allows this weakly cationic dye to penetrate cell membranes and concentrate in lysosomes. The dye is then released from the viable cells using an acidified ethanol solution, and the dye's absorbance is spectrophotometrically measured.

Schirmer et al. (1997) were the first to describe the use of these three dyes to provide an overview of the cytotoxicity/cytoprotectivity of treatments to cells in 96-well plates [43]. This protocol was followed in this experiment with minimal changes. In summary, our method measured three cell viability parameters on the same set of cells at the same time without interfering. After a $24 \mathrm{~h}$ treatment, cells seeded in 96-well plates were treated with a solution of almarBlue and CFDA-AM in Eagle's minimal essential medium (SigmaAldrich, St. Louis, MO, USA). After an hour of incubation, the cells were measured at different wavelengths. The cells were then rinsed in PBS and exposed to neutral red dye in the minimal essential medium for $1 \mathrm{~h}$. After incubation, the cells were rinsed twice with PBS (phosphate-buffered saline; Sigma-Aldrich, St. Louis, MO, USA) and exposed to the lysis buffer for $30 \mathrm{~min}$ before being measured at a specific wavelength. The multiple endpoint assay is based on measurements performed at 525/580-640 $\mathrm{nm}$ for alamarBlue, 490/510-570 nm for CFDA-AM, and 525/660-720 nm for NR with a Glomax Multi + Combined Spectro-Fluoro Luminometer (Promega Corp., Madison, WI, USA). The data were collected from three different experiments and expressed as a percentage of the control group, which was set at $100 \%$.

\subsection{Evaluation of Testosterone and Progesterone Production}

The media were collected after a $24 \mathrm{~h}$ culture in the presence of various bisphenol concentrations and centrifuged at $300 \times g$ for $10 \mathrm{~min}$ at $4{ }^{\circ} \mathrm{C}$. The supernatant was stored at a temperature of $-20^{\circ} \mathrm{C}$. To quantify testosterone and progesterone directly from aliquots of the culture medium, an enzyme-linked immunosorbent assay (ELISA) was performed. The concentration of progesterone in the culture media was determined using an enzymelinked immunosorbent assay (ELISA) kit (Cat. \#K00225, Dialab, Wiener Neudorf, Australia), according to the manufacturer's instructions. ELISA kits (Cat. \#K00234, Dialab, Wiener Neudorf, Austria) were used to measure testosterone concentrations. An ELISA reader was used to measure the absorbance at $450 \mathrm{~nm}$ (Mul-ti-scan FC, ThermoFisher Scientific, Vantaa, Finland).

\subsection{Statistical Analysis}

The data gathered were statistically analyzed using GraphPad Prism 8 (GraphPad Software Incorporated, San Diego, CA, USA). The initial step was to evaluate descriptive statistical parameters (minimum, maximum, and standard error). One-way analysis of variance (ANOVA) and Dunnett's multiple comparison test were used to examine differences between bisphenol treatments and the control. The significance levels were established at ${ }^{* * *}(p<0.001),{ }^{* *}(p<0.01)$, and ${ }^{*}(p<0.05)$. Data were obtained from three sets of independent experiments $(n=3)$. The results were presented as means (SEM) of mitochondrial activity percent, metabolic activity percent, membrane integrity percent, lysosomal activity percent, progesterone percent, and testosterone percent of a control group.

\section{Results}

\subsection{Mitochondrial Activity}

Our findings show that bisphenols may act dose-dependently as a stimulant at low doses or as an inhibitor at high levels, based on the MTT test. In the case of cells treated with BPB, as shown in Figure 1, we observed slightly increased mitochondrial activity in the case of cells treated with $0.1 \mu \mathrm{M} \mathrm{BPB}(p>0.05)$. Significantly lower $(p<0.01)$ values 
were observed in the experimental groups with the addition of 50, 75, and $100 \mu \mathrm{M} \mathrm{BPB}$ in comparison with a control group. Similar results were obtained in the case of BPF, but with more pronounced differences. The lowest concentrations of BPF caused stimulation of H295R cells' mitochondrial activity without significant changes $(p>0.05)$, but higher doses $(1-100 \mu \mathrm{M})$ of BPF caused inhibition of mitochondrial activity $(p<0.001)$. As seen in Figure 1, 0.1 and $0.5 \mu \mathrm{M}$ BPS caused a nonsignificant increase in mitochondrial activity. On the contrary, 1, 50, and $100 \mu \mathrm{M}$ BPS after $24 \mathrm{~h}$ of culture inhibited cell mitochondrial activity, resulting in a significant decrease in values $(p<0.05)$.
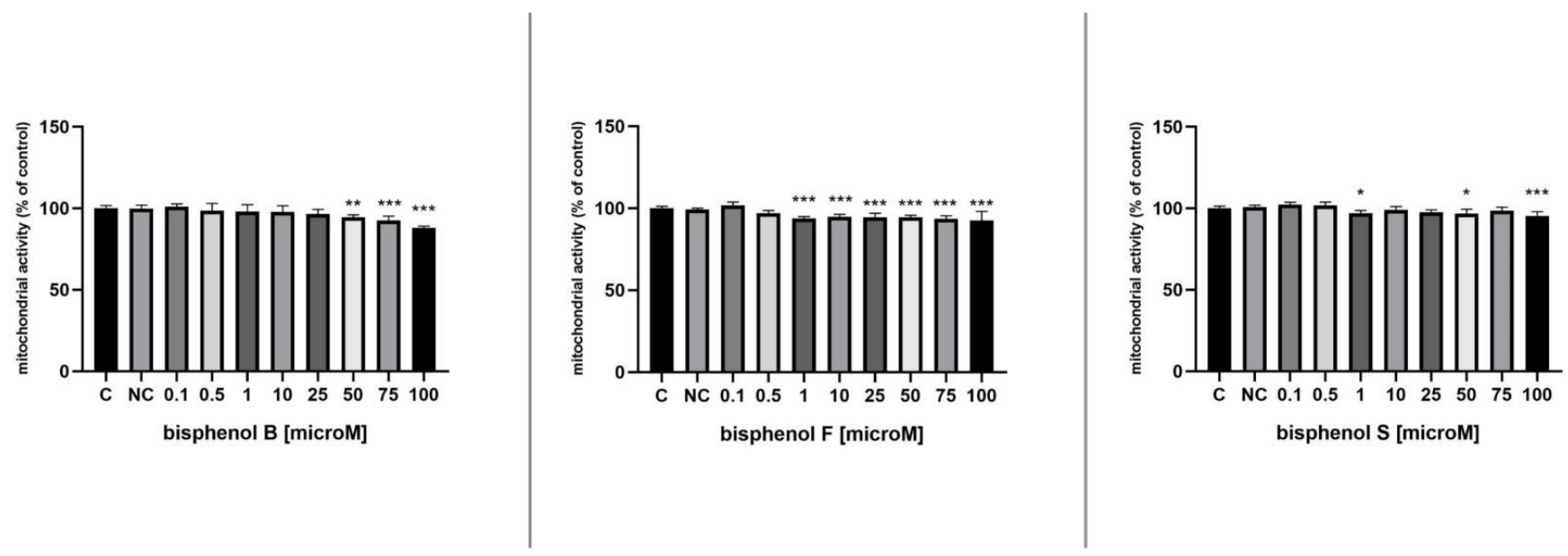

Figure 1. The impact of bisphenol B, F, and S on H295R cells' mitochondrial activity in vitro. Abbreviations: C-control group, NC-negative control. The mean $( \pm$ SEM) optical density percent of the control (untreated) and treated (bisphenol) groups is represented by each bar. The data were collected from three separate experiments. Between the control and experimental groups, the significance levels were established at ${ }^{* *}(p<0.001),{ }^{* *}(p<0.01)$, and ${ }^{*}(p<0.05)$.

\subsection{Metabolic Activity}

Bisphenols may function dose-dependently as a stimulant at low concentrations or as an inhibitor at high concentrations, according to an analysis of metabolic activity using alamarBlue. As seen in Figure 2, in the case of cells treated with BPB, the lowest concentration $(0.1 \mu \mathrm{M})$ led to an increase in metabolic activity without significant changes $(p>0.05)$. Higher doses of BPB, on the other hand, inhibited cell metabolic activity after $24 \mathrm{~h}$ of culture, with a significant drop in values $(p>0.001)$ for experimental groups supplemented with 1-100 $\mu \mathrm{M}$, compared with an untreated control group. Similar results were obtained in the case of BPF. The lowest concentrations of BPF caused stimulation of H295R cells' metabolic activity $(0.1 \mu \mathrm{M} ; p<0.05)$, but higher doses $(10-100 \mu \mathrm{M})$ of BPF caused inhibition of metabolic activity $(p<0.01)$. The metabolic activity of cells cultured with BPS showed a similar trend in the concerning experiment, where H295R cells were exposed to BPS for $24 \mathrm{~h}$, although with less pronounced differences than in the previous cases. Lower concentrations of BPS $(0.1$ and $0.5 \mu \mathrm{M})$ caused stimulation of H295R cells' mitochondrial activity $(p>0.05)$. Significantly decreased $(p<0.01)$ metabolic activity was recorded only in the experimental group treated with the highest dose of BPS $(100 \mu \mathrm{M})$ $(p<0.01)$. 

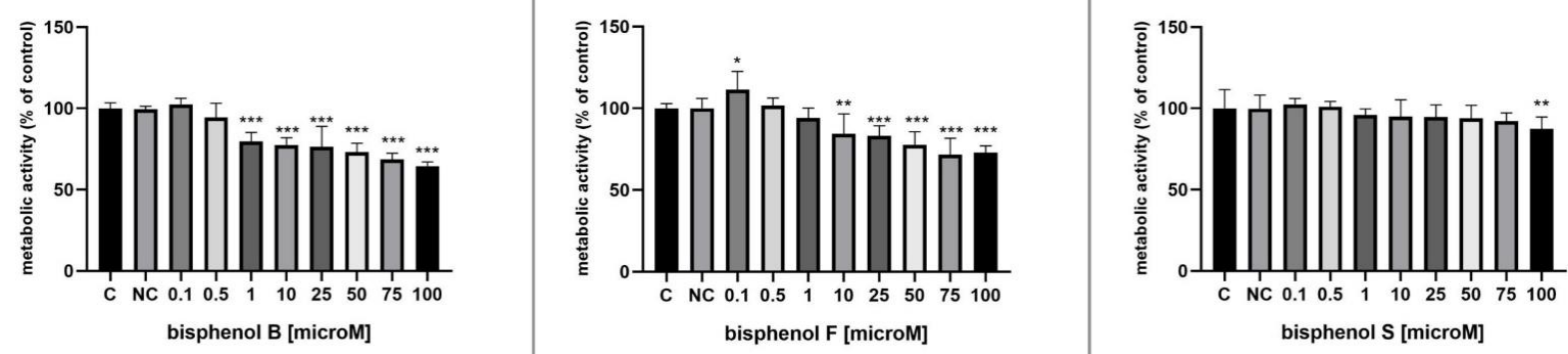

Figure 2. The impact of bisphenol B, F, and S on H295R cells metabolic activity in vitro. Abbreviations: C—control group, $\mathrm{NC}$-negative control. The mean $( \pm \mathrm{SEM})$ optical density percent of the control (untreated) and treated (bisphenol) groups is represented by each bar. The data were collected from three separate experiments. Between the control and experimental groups, the significance levels were established at ${ }^{* *}(p<0.001),{ }^{* *}(p<0.01)$, and ${ }^{*}(p<0.05)$.

\subsection{Membrane Integrity}

The effect of bisphenols on the integrity of the H295R cells cell membrane is presented in Figure 3. Bisphenols have a biphasic effect on membrane integrity, similar to previous experiments (mitochondrial activity, metabolic activity). Cell membrane integrity measurement in H295R cells treated with BPB for $24 \mathrm{~h}$ showed an increase in the experimental group treated with $0.1 \mu \mathrm{M}(p>0.05)$ and decrease in experimental groups treated with $25,50,75$, and $100 \mu \mathrm{M}(p<0.05)$. Only in experimental groups supplemented with higher doses of $\operatorname{BPF}(25,50,75$, and $100 \mu \mathrm{M})$, which resulted in a decline in values, did cell membrane integrity measurements in H295R cells treated with BPF for $24 \mathrm{~h}$ indicate significant alterations $(p<0.01)$ (Figure 3$)$; on the contrary, we observed a nonsignificant increase in experimental groups treated with a lower concentration of BPF $(0.1$ and $0.5 \mu \mathrm{M})$. We observed the strongest substantial impact on membrane integrity in bisphenol S-treated groups. Significant changes $(p<0.01)$ were recorded in groups treated with $0.5,1,10,25,50$, 75 , and $100 \mu \mathrm{M}$ BPS - we observed a significant decline in membrane integrity. The lowest concentrations of BPS $(0.1 \mu \mathrm{M})$ caused non-significantly increased cell membrane integrity in H295R cells in comparison with the control group.
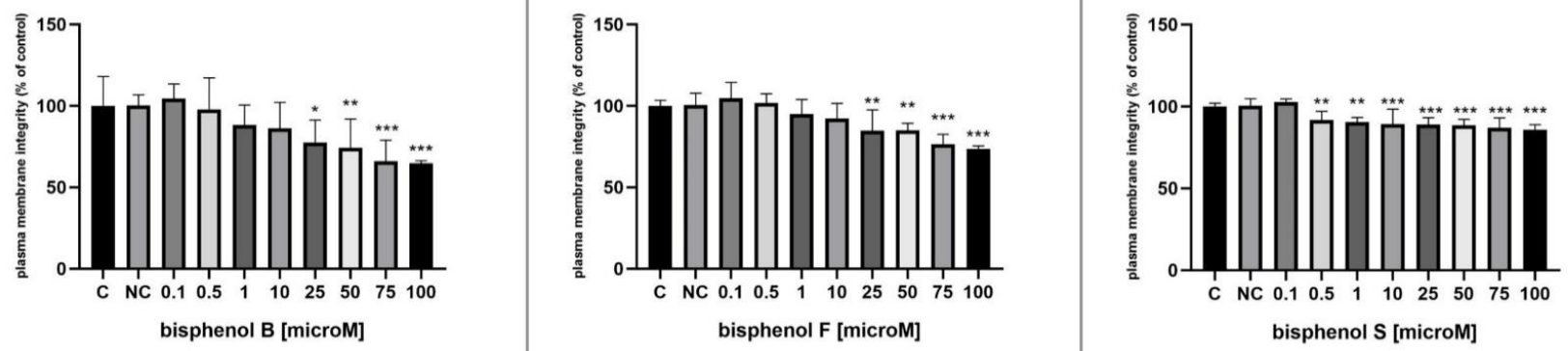

Figure 3. The impact of bisphenol B, F, and S on H295R cells membrane integrity in vitro. Abbreviations: C—control group, NC-negative control. The mean $( \pm$ SEM) optical density percent of the control (untreated) and treated (bisphenol) groups is represented by each bar. The data were collected from three separate experiments. Between the control and experimental groups, the significance levels were established at ${ }^{* * *}(p<0.001),{ }^{* *}(p<0.01)$, and $*(p<0.05)$. 


\subsection{Lysosomal Activity}

Figure 4 shows the effect of bisphenols on lysosomal activity in H295R cells. BPB at $0.1 \mu \mathrm{M}$ resulted in a non-significant $(p>0.05)$ elevation of lysosomal function compared with the control group, but higher dosages $(25,50,75$, and $100 \mu \mathrm{M})$ resulted in a significant $(p<0.001)$ decrease in lysosomal activity. In the case of BPF, significant changes $(p<0.05)$ were recorded only in experimental groups of cells cultivated in the presence of higher concentrations $(25,50,75$, and $100 \mu \mathrm{M})$. Lower concentrations of BPF $(0.1,0.5,1 \mu \mathrm{M})$ improved lysosomal activity of cells non-significantly $(p>0.05)$ compared with the control group. Similarly, experimental groups treated with $0.1(p>0.05), 0.5(p<0.001)$, and $1 \mathrm{M}$ $(p>0.05)$ of BPS showed an increase in lysosomal activity. Experimental groups of cells cultivated in the presence of higher concentrations $(25,50,75$, and $100 \mu \mathrm{M})$ of BPF showed significantly lower $(p<0.01)$ lysosomal activity when compared against the control group.
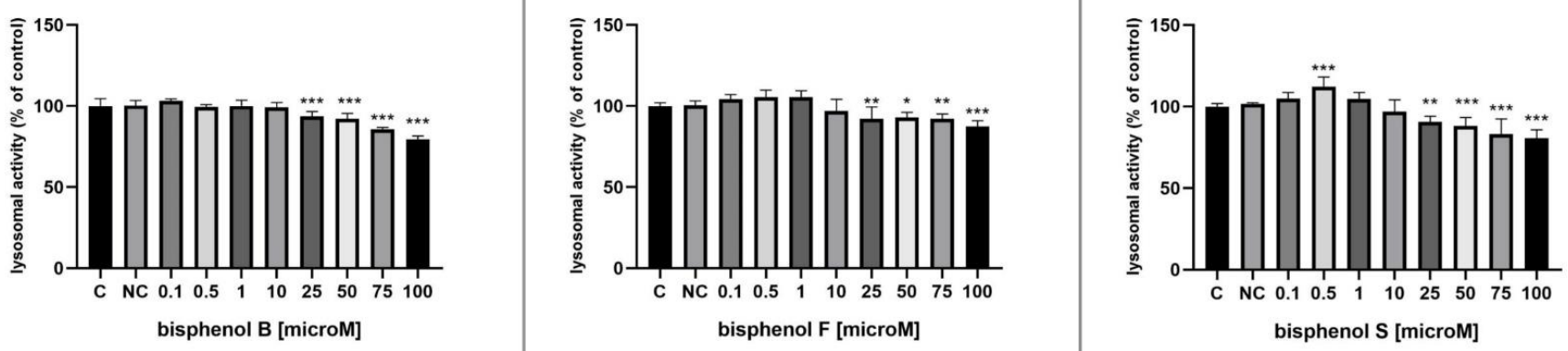

Figure 4. The impact of bisphenol B, F, and S on H295R cells lysosomal activity in vitro. Abbreviations: C—control group, NC-negative control. The mean $( \pm$ SEM) optical density percent of the control (untreated) and treated (bisphenol) groups is represented by each bar. The data were collected from three separate experiments. Between the control and experimental groups, the significance levels were established at ${ }^{* * *}(p<0.001),{ }^{* *}(p<0.01)$, and ${ }^{*}(p<0.05)$.

\subsection{Progesterone Secretion}

The impact of bisphenols on progesterone secretion in vitro is shown in Figure 5. A total of $24 \mathrm{~h}$ of H295R cells cultivation with BPB showed significant changes with increased production of progesterone in samples supplemented with 0.1 and $1 \mu \mathrm{M}$ BPB $(p<0.01)$ and non-significant increase in samples supplemented with $0.5 \mu \mathrm{M}$, on the other hand, higher concentrations of $\mathrm{BPB}(25,50,75$, and $100 \mu \mathrm{M})$ led to significant $(p<0.001)$ reduction in progesterone biosynthesis in treated cells. After BPF was added to the culture media, it resulted in significantly higher $(p<0.05)$ production of progesterone in experimental groups supplemented with $0.1-75 \mu \mathrm{M}$ and significantly lower $(p<0.01)$ production of progesterone in the experimental group supplemented with $100 \mu \mathrm{M}$. Progesterone levels were also significantly $(p<0.01)$ elevated, as seen in Figure 5, in the presence of $0.1 \mu \mathrm{M}$ of BPS and higher concentrations of BPS $(25-100 \mu \mathrm{M})$ led to a significant $(p<0.001)$ reduction in progesterone biosynthesis in cells exposed to BPS; these results are similar to results obtained after cultivation with BPB. 

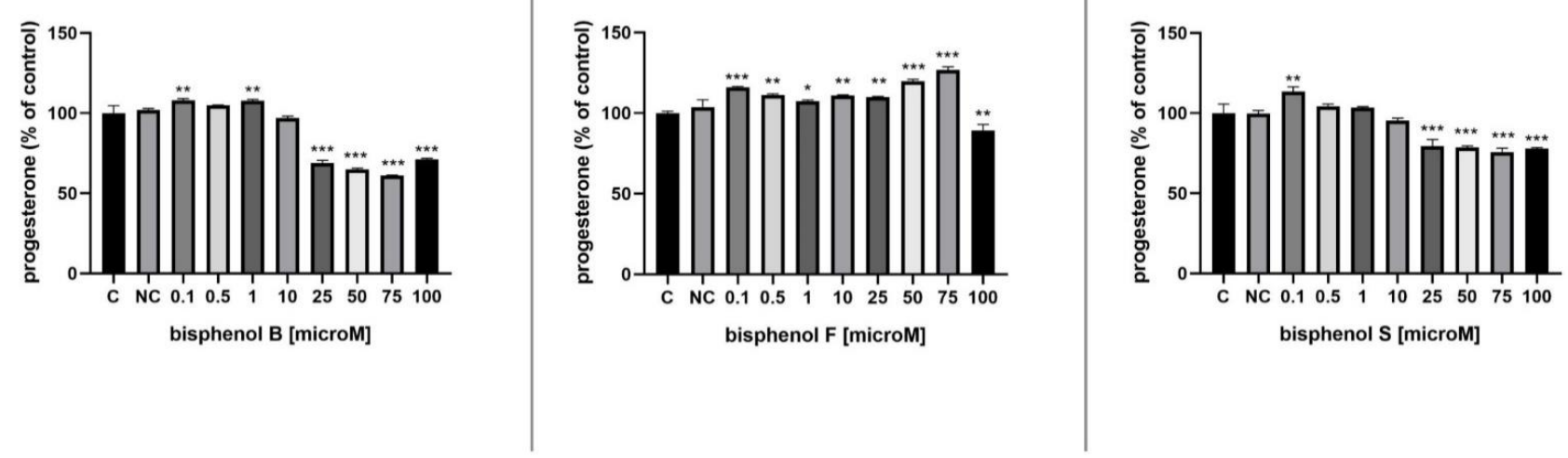

Figure 5. The impact of bisphenol B, F, and S on H295R cells progesterone secretion in vitro. Abbreviations: C-control group, NC-negative control. The mean $( \pm$ SEM) optical density percent of the control (untreated) and treated (bisphenol) groups is represented by each bar. The data were collected from three separate experiments. Between the control and experimental groups, the significance levels were established at ${ }^{* *}(p<0.001),{ }^{* *}(p<0.01)$, and $*(p<0.05)$.

\subsection{Testosterone Secretion}

We observed significant changes in testosterone production after $24 \mathrm{~h}$ of cultivation. The effect of bisphenols on the testosterone biosynthesis in H295R cells is presented in Figure 6. When compared with the control group, BPB concentrations of $0.1 \mu \mathrm{M}$ resulted in a significant increase $(p<0.01)$ in testosterone secretion, whereas the highest dosages $(25-100 \mu \mathrm{M})$ resulted in a significant decrease $(p<0.001)$ in testosterone secretion. Significantly lower $(p<0.01)$ values were also observed in the experimental groups with the addition of 50, 75, and $100 \mu \mathrm{M}$ BPF in comparison with a control group, but the lowest concentration $(0.1 \mu \mathrm{M})$ BPF caused a significant increase $(p<0.01)$ in testosterone secretion by H295R cells. Incubation of H295R cells with BPS for $24 \mathrm{~h}$ resulted in significant changes, with increased testosterone production in samples supplemented with 0.1 and $0.5 \mu \mathrm{M}$ BPS $(p<0.01)$, while higher concentrations of BPS $(50,75$, and $100 \mu \mathrm{M})$ resulted in significant $(p<0.01)$ testosterone biosynthesis reduction in treated cells.
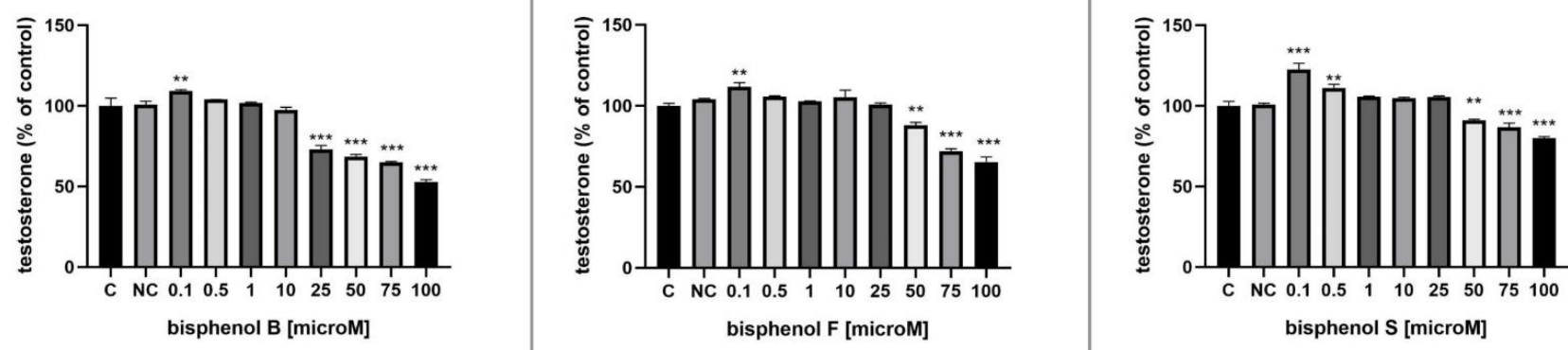

Figure 6. The impact of bisphenol B, F, and S on H295R cells testosterone secretion in vitro. Abbreviations: C-control group, NC-negative control. The mean $( \pm$ SEM) optical density percent of the control (untreated) and treated (bisphenol) groups is represented by each bar. The data were collected from three separate experiments. Between the control and experimental groups, the significance levels were established at ${ }^{* * *}(p<0.001),{ }^{* *}(p<0.01)$. 


\section{Discussion}

Because of BPA's endocrine-disrupting capabilities and carcinogenic potential, it is progressively being replaced with safer equivalents such as BPB, BPS, and BPF in the manufacturing of polycarbonate plastics and epoxy resins [35]. BPB, BPF, and BPF have all been widely used as BPA substitutes, because of their similar chemical properties, these alternatives may have BPA-like effects. According to environmental monitoring data, these compounds have the potential to become global food contaminants and environmental pollutants in the future. Although these bisphenols are commonly utilized to make a range of daily household items, little is known about their capacity to influence and disrupt steroidogenic pathways, as well as the method by which these chemicals might interfere with steroidogenic enzyme function. Various endocrine disruptors including BPB, BPF, and BPS can have mixed effects on the endocrine system of animals and humans, by acting as direct agonists or antagonists of steroid receptors, as well as potential inducers or inhibitors of steroidogenic enzymes [5,44,45]. The influence of various quantities of $\mathrm{BPB}, \mathrm{BPF}$, and BPS on the steroidogenesis of the human H295R cell line is demonstrated in these in vitro experiments (specifically the production of progesterone and testosterone). Furthermore, we assessed the mitochondrial activity and viability parameters (plasma membrane integrity, lysosomal and metabolic activity).

We observed that BPB, BPF, and BPS significantly decreased mitochondrial activity in higher concentrations (50-100 $\mu \mathrm{M})$. According to the MTT assay, the least toxic was BPS $(100 \mu \mathrm{M}=95.24 \pm 0.77 \%)$ followed by BPF $(100 \mu \mathrm{M}=92.38 \pm 2.01 \%)$. BPB showed the highest toxicity $(100 \mu \mathrm{M}=87.92 \pm 0.40 \%)$. Bisphenol cytotoxicity was shown to increase with increased exposure time and concentration [4]. Our findings are following those of Zhang et al. (2011), who examined the effect of BPA on mitochondrial activity of human H295R cells. Results of this in vitro experiment indicate that BPA at lower concentrations $(0.039-10 \mu \mathrm{M})$ did not result in any significant inhibition of cell viability [5]. The concentrations of 1 and $10 \mu \mathrm{M}$ are comparable to the range of blood levels found in persons who had been occupationally exposed [7]. Our findings are supported by another study, which evaluated the cytotoxicity of BPF and BPS on the H295R human adrenocortical carcinoma cell line found that cytotoxicity was not seen at most of the doses examined. Only the highest concentration $(100 \mu \mathrm{M})$ reduced viability significantly [46]. Feng et al. (2016) used the CCK-8 test to investigate the effects of BPA, BPAF, BPF, and BPS on cell viability. According to their in vitro study, BPAF had the highest cytotoxicity, with 16.1 percent cell viability at $200 \mu \mathrm{M}$ for $24 \mathrm{~h}$; BPS (62.6 percent cell viability at $200 \mu \mathrm{M}$ for $24 \mathrm{~h}$ ) was less toxic than BPA (64.7 percent cell viability at $200 \mu \mathrm{M}$ for $24 \mathrm{~h}$ ), and BPF was the least toxic, with no cytotoxicity even at $200 \mu \mathrm{M}$ [4]. Lan et al. (2017) demonstrated the concentration-dependent biphasic impact of bisphenol $\mathrm{A}$ in an in vitro research with MA10 cells (epithelial-like tumor cell line of Leydig cells from C57BL/6J mice). They treated MA-10 cells treated with various doses $(0.01$ to $200.0 \mu \mathrm{M})$ of BPA. Results showed that low doses $(0.01-0.1 \mu \mathrm{M})$ of BPA enhanced cell viability, while higher doses $(100-200 \mu \mathrm{M})$ decreased cell viability [47]. After treatment with high doses of BPS $(100 \mu \mathrm{M})$ and BPF $(100 \mu \mathrm{M})$, Huang et al. (2020) found that the viability of KGN cells was significantly reduced [48]. For $24 \mathrm{~h}$, Qi et al. (2020) treated a human ovarian granulosa cell line (KGN) with increasing concentrations of BPA $(0.1,1,10$, and $100 \mu \mathrm{M})$. BPA concentrations of $0.1,1$, and $10 \mu \mathrm{M}$ did not affect the viability of KGN, while $100 \mu \mathrm{M}$ caused a statistically significant reduction in viability [49]. In our experiments, we treated H295R cells with increasing concentrations $(0.1,0.5,1,10,25,50,75$, and $100 \mu \mathrm{M})$ of BPB, BPF, and BPS, and treatment with all bisphenols with $100 \mu \mathrm{M}$ resulted in a decrease in viability parameters.

After exposure to 30, 50, and $70 \mu \mathrm{M}$ BPF (elevated by 733 percent, 1122 percent, and 1273 percent, respectively), Feng et al. (2016) reported increasing levels of progesterone in a dose-dependent manner, while treatment to 1 and $10 \mu \mathrm{M}$ BPS resulted in significant elevation of progesterone (increased by 50.3 percent and 91.0 percent, respectively) [4]. Their findings are consistent with the findings of our experiments; we observed an increase in free progesterone level after $24 \mathrm{~h}$ of BPF exposure for the concentrations 0.1-75 $\mu \mathrm{M}$. 
Only the highest concentration of BPF $(100 \mu \mathrm{M})$ resulted in a decrease in free progesterone. For $24 \mathrm{~h}$, Qi et al. (2020) treated a KGN cell line with increasing concentrations of BPA $(0.1,1,10$, and $100 \mu \mathrm{M})$. KGN's progesterone biosynthesis was significantly reduced after treatment with $10 \mu \mathrm{M}$ BPA, but during our experiments, we observed a significant increase in testosterone production after treatment with $10 \mu \mathrm{M}$ BPF and no significant changes after treatment with $10 \mu \mathrm{M}$ BPB and BPS [49].

There is growing evidence that many chemicals released into the environment can disturb the endocrine system. Certain environmental pollutants can disrupt hormonal balance and interfere with the activities of critical enzymes involved in steroidogenesis, causing or contributing to hormonal disturbance [1]. Goldinger et al. (2015) observed a significant decrease in free testosterone level in an angiotensin-II-responsive steroid-producing adrenocortical cell line culture medium after $48 \mathrm{~h}$ of BPS exposure for the concentrations of 1-100 $\mu \mathrm{M}$ [46]. After $24 \mathrm{~h}$ of BPS exposure in H295R cell culture media, we observed a decrease in free testosterone levels in culture media for the concentrations 50-100 $\mu \mathrm{M}$. BPS caused a concentration-dependent reduction in testosterone production at $10-70 \mu \mathrm{M}$ (reduced by 34.0 percent at $10 \mu \mathrm{M}, 69.1 \%$ at $30 \mu \mathrm{M}, 82.4$ percent at $50 \mu \mathrm{M}$, and $86.8 \%$ at $70 \mu \mathrm{M}$ ), according to Feng et al. (2016). However, no significant changes were found in any of the BPF subgroups that were examined [4]. On the other hand, Goldinger et al. (2016) observed an increase in free testosterone level after $48 \mathrm{~h}$ of BPF exposure for the concentrations 1-30 $\mu \mathrm{M}$; only the highest concentration $(100 \mu \mathrm{M})$ resulted in a decrease in free testosterone, which is in agreement with our results because we observed an increase in free testosterone level after $24 \mathrm{~h}$ of BPF exposure for the concentrations 1-30 $\mu \mathrm{M}$. However, one in three duplicates of their experiment did not match the other two, resulting in a greater standard deviation than expected [46]. Roelofs et al. (2015) observed a significant increase in testosterone concentration in MA-10 Leydig cells after a 48 h-long exposure to $\mathrm{BPF}$ at a concentration of $100 \mu \mathrm{M}$; however, in our experiment, we observed a significant decrease in testosterone concentration after $24 \mathrm{~h}$ exposure to $100 \mu \mathrm{M}$ of BPF [50].

Endocrine disruptors can disrupt steroid hormone production by inducing or inhibiting enzymatic gene expression via steroid hormone receptors and/or altering enzymatic activity directly or indirectly. Thus, the effect of endocrine disruptors is dependent on the type of issue, pollutant concentrations, bioaccumulation, and stability, as well as the type of exposure (in vitro or in vivo) and duration of exposure. Our findings suggest that testosterone is more sensitive to bisphenol exposure than progesterone. The effect of $17 \mathrm{~b}$-hydroxysteroid dehydrogenase's activity is likely to be more sensitive, resulting in lower testosterone release if compared with progesterone. Feng et al. (2016) evaluated transcription levels of corresponding genes encoding steroidogenic enzymes (StAR (Steroidogenic Acute Regulatory Protein), FDX-1 (Ferredoxin 1), CYP11A1 Cytochrome P450 Family 11 Subfamily A Member 1), HSD3B2 (Hydroxy-Delta-5-Steroid Dehydrogenase, 3 Beta- Additionally, Steroid Delta-Isomerase 2), CYP21A2 (Cytochrome P450 Family 21 Subfamily A Member 2), CYP17A1 (Cytochrome P450 Family 17 Subfamily A Member 1), and 17bHSD (17 $\beta$-Hydroxysteroid dehydrogenases)). The molecular mechanisms by which BPA increases STAR expression are still not fully clarified [4]. In human cumulus granulosa cells, Pogrmic-Majkic et al. (2019) found that increased STAR expression is mediated through the PPAR/EGFR/ERK1/2 (Peroxisome proliferator-activated Receptor, Epidermal Growth Factor Receptor, Extracellular signal-regulated kinases) pathway [51]. Progesterone is an important precursor of hormones such as aldosterone, cortisol, testosterone, and $17 \mathrm{~b}$-estradiol in the adrenal glands. It is generated from cholesterol via sequential re-actions catalyzed by StAR, FDX-1, CYP11A1, and HSD3B2. Gene transcription levels of StAR and CYP11A1 were not significantly modified were at any concentrations of BPF and BPS. BPF at concentrations up to $50 \mu \mathrm{M}$ caused a statistically significant inhibition of HSD3B2 gene expression. However, BPS did not disrupt this gene expression at any tested concentration. Gene transcription involved in testosterone biosynthesis was also measured. Testosterone is generated from progesterone via sequential reactions catalyzed by CYP17A1 and 17b-HSD (17 beta-Hydroxysteroid dehydrogenase). All four compounds 
downregulated the gene expression of CYP17A1 in a dose-dependent manner starting at concentrations as low as $1 \mu \mathrm{M}$ for BPA and BPAF and at concentrations from $10 \mu \mathrm{M}$ BPF to $30 \mu \mathrm{M}$ for BPS. However, gene expression of $17 \mathrm{~b}$ - hydroxysteroid was not interrupted with any of bisphenols across the entire range of concentration, although testosterone production significantly decreased after bisphenol exposure [4]. According to Amar et al. (2020), BPS treatment decreased protein expression of CYP11A1, a steroidogenic enzyme involved in the transformation of cholesterol into pregnenolone, the precursor of progesterone, and therefore a lower pregnenolone concentration might lead to lower progesterone synthesis and release. BPS, on the other hand, did not affect HSD3B1, which is involved in the conversion of pregnenolone to progesterone [52].

Steroid hormone biosynthesis in steroidogenic cells is regulated through trophic hormone activation of protein kinase A (PKA) signaling pathways. Many examples of steroid synthesis regulation via pathways other than the PKA pathway have been identified. In some situations, these pathways work independently of PKA activation, whereas in others, they act synergistically with it. Additional signaling pathways and components include the protein kinase $\mathrm{C}$ pathway, arachidonic acid metabolites, growth factors, chloride ion, and the calcium messenger system [53].

Chu et al. (2018) demonstrated that low-dose BPA (1-1000 nM) influenced the ERK signaling pathway and resulted in hormone reductions in human placental cells [54]. Amar et al. (2020) investigated the MAPK3/1 signaling pathway in human granulosa cells in the presence or absence of $10 \mu \mathrm{M}$ BPS after $5,10,30$, and 60 min of treatment. After $5 \mathrm{~min}$, a transient 3.7-fold increase in MAPK3/1 phosphorylation was detected in control cells (HGC treated with media alone) ( $p$ 0.0001). After 5 min with $10 \mu \mathrm{M}$ BPS, there was a comparable 4.1-fold increase in MAPK3/1 phosphorylation [52].

\section{Conclusions}

In conclusion, we demonstrated that BPB, BPF, and BPS could affect progesterone and testosterone secretion, as well as affect cell mitochondrial activity, plasma membrane integrity, and lysosomal and metabolic activity. Our research has a few limitations. For the final concentration of BPs, we used data from previous studies. However, the extent to which BPs are taken up by cells is unclear, and our goal was to investigate the possible mechanisms of BPs activity. Another limitation is that the period of exposure in our study was relatively short. Long-term exposure and in vivo experiments may provide more accurate data on their effects.

Author Contributions: Conceptualization, N.K. and N.L.; methodology, N.K., H.G., T.J. and K.T.; validation, N.L. and Ł.J.B.; formal analysis, N.K.; investigation, N.K. and N.L.; data curation, N.K. and H.G.; writing—original draft preparation, N.K. and T.J.; writing-review and editing, N.L. and Ł.J.B.; supervision, N.L.; project administration, N.L. and K.T.; funding acquisition, N.L. All authors have read and agreed to the published version of the manuscript.

Funding: This research was funded by the Scientific Agency of the Slovak Republic VEGA No. 1/0083/21, No. 1/0038/19, No. 1/0163/18 and by the Slovak Research and Development Agency Grant APVV-20-0218, APVV-19-0243, APVV-18-0312.

Institutional Review Board Statement: Not applicable.

Informed Consent Statement: Not applicable.

Data Availability Statement: All data are provided in the manuscript.

Conflicts of Interest: The authors declare no conflict of interest.

\section{References}

1. Sanderson, J.T. The Steroid Hormone Biosynthesis Pathway as a Target for Endocrine-Disrupting Chemicals. Toxicol. Sci. 2006, 94, 3-21. [CrossRef] [PubMed] 
2. Jambor, T.; Kovacikova, E.; Greifova, H.; Kovacik, A.; Libova, L.; Lukac, N. Assessment of the effective impact of bisphenols on mitochondrial activity and steroidogenesis in a dose-dependency in mice TM3 Leydig cells. Physiol. Res. 2019, 68, 689-693. [CrossRef]

3. Reif, D.M.; Martin, M.T.; Tan, S.W.; Houck, K.A.; Judson, R.S.; Richard, A.M.; Knudsen, T.B.; Dix, D.J.; Kavlock, R.J. Endocrine profiling and prioritization of environmental chemicals using ToxCast data. Environ. Health Perspect. 2010, 118, 1714-1720. [CrossRef]

4. Feng, Y.; Jiao, Z.; Shi, J.; Li, M.; Guo, Q.; Shao, B. Effects of bisphenol analogues on steroidogenic gene expression and hormone synthesis in H295R cells. Chemosphere 2016, 147, 9-19. [CrossRef]

5. Zhang, X.; Chang, H.; Wiseman, S.; He, Y.; Higley, E.; Jones, P.; Wong, C.K.; Al-Khedhairy, A.; Giesy, J.P.; Hecker, M. Bisphenol A disrupts steroidogenesis in human H295R cells. Toxicol. Sci. Off. J. Soc. Toxicol. 2011, 121, 320-327. [CrossRef] [PubMed]

6. Zhang, Z.; Alomirah, H.; Cho, H.S.; Li, Y.F.; Liao, C.; Minh, T.B.; Mohd, M.A.; Nakata, H.; Ren, N.; Kannan, K. Urinary bisphenol A concentrations and their implications for human exposure in several Asian countries. Environ. Sci. Technol. 2011, 45, 7044-7050. [CrossRef]

7. Gonçalves, G.D.; Semprebon, S.C.; Biazi, B.I.; Mantovani, M.S.; Fernandes, G. Bisphenol A reduces testosterone production in TM3 Leydig cells independently of its effects on cell death and mitochondrial membrane potential. Reprod. Toxicol. 2018, 76, 26-34. [CrossRef] [PubMed]

8. Samardzija, D.; Pogrmic-Majkic, K.; Fa, S.; Stanic, B.; Jasnic, J.; Andric, N. Bisphenol A decreases progesterone synthesis by disrupting cholesterol homeostasis in rat granulosa cells. Mol. Cell. Endocrinol. 2018, 461, 55-63. [CrossRef]

9. Moral, R.; Wang, R.; Russo, I.H.; Lamartiniere, C.A.; Pereira, J.; Russo, J. Effect of prenatal exposure to the endocrine disruptor bisphenol A on mammary gland morphology and gene expression signature. J. Endocrinol. 2008, 196, 101-112. [CrossRef] [PubMed]

10. Miyawaki, J.; Sakayama, K.; Kato, H.; Yamamoto, H.; Masuno, H. Perinatal and postnatal exposure to bisphenol a increases adipose tissue mass and serum cholesterol level in mice. J. Atheroscler. Thromb. 2007, 14, 245-252. [CrossRef]

11. Chapin, R.E.; Adams, J.; Boekelheide, K.; Gray, L.E.; Hayward, S.W., Jr.; Lees, P.S.; McIntyre, B.S.; Portier, K.M.; Schnorr, T.M.; Selevan, S.G.; et al. NTP-CERHR expert panel report on the reproductive and developmental toxicity of bisphenol A. Birth Defects Res. Part B Dev. Reprod. Toxicol. 2008, 83, 157-395. [CrossRef]

12. Vandenberg, L.N.; Hauser, R.; Marcus, M.; Olea, N.; Welshons, W.V. Human exposure to bisphenol A (BPA). Reprod. Toxicol. 2007, 24, 139-177. [CrossRef] [PubMed]

13. Rochester, J.R. Bisphenol A and human health: A review of the literature. Reprod. Toxicol. 2013, 42, 132-155. [CrossRef]

14. Rezg, R.; El-Fazaa, S.; Gharbi, N.; Mornagui, B. Bisphenol A and human chronic diseases: Current evidences, possible mechanisms, and future perspectives. Environ. Int. 2014, 64, 83-90. [CrossRef] [PubMed]

15. Beronius, A.; Rudén, C.; Håkansson, H.; Hanberg, A. Risk to all or none? A comparative analysis of controversies in the health risk assessment of Bisphenol A. Reprod. Toxicol. 2010, 29, 132-146. [CrossRef]

16. Birnbaum, L.S.; Bucher, J.R.; Collman, G.W.; Zeldin, D.C.; Johnson, A.F.; Schug, T.T.; Heindel, J.J. Consortium-based science: The NIEHS's multipronged, collaborative approach to assessing the health effects of bisphenol A. Environ. Health Perspect. 2012, 120, 1640-1644. [CrossRef] [PubMed]

17. Calafat, A.M.; Ye, X.; Wong, L.Y.; Reidy, J.A.; Needham, L.L. Exposure of the U.S. population to bisphenol A and 4-tertiaryoctylphenol: 2003-2004. Environ. Health Perspect. 2008, 116, 39-44. [CrossRef]

18. EFSA. Scientific Opinion on the risks to public health related to the presence of bisphenol A (BPA) in foodstuffs. EFSA J. 2015, 13, 3978. [CrossRef]

19. Kang, J.H.; Kondo, F.; Katayama, Y. Human exposure to bisphenol A. Toxicology 2006, 226, 79-89. [CrossRef]

20. Wu, J.; Huang, D.; Su, X.; Yan, H.; Sun, Z. Oral administration of low-dose bisphenol A promotes proliferation of ventral prostate and upregulates prostaglandin D2 synthase expression in adult rats. Toxicol. Ind. Health 2016, 32, 1848-1858. [CrossRef]

21. Wang, F.; Hua, J.; Chen, M.; Xia, Y.; Zhang, Q.; Zhao, R.; Zhou, W.; Zhang, Z.; Wang, B. High urinary bisphenol A concentrations in workers and possible laboratory abnormalities. Occup. Environ. Med. 2012, 69, 679-684. [CrossRef] [PubMed]

22. Heinälä, M.; Ylinen, K.; Tuomi, T.; Santonen, T.; Porras, S.P. Assessment of Occupational Exposure to Bisphenol A in Five Different Production Companies in Finland. Ann. Work Expo. Health 2017, 61, 44-55. [CrossRef]

23. Kitamura, S.; Suzuki, T.; Sanoh, S.; Kohta, R.; Jinno, N.; Sugihara, K.; Yoshihara, S.; Fujimoto, N.; Watanabe, H.; Ohta, S. Comparative study of the endocrine-disrupting activity of bisphenol A and 19 related compounds. Toxicol. Sci. Off. J. Soc. Toxicol. 2005, 84, 249-259. [CrossRef]

24. Rosenschöld, J.M.A.; Honkela, N.; Hukkinen, J.I. Addressing the temporal fit of institutions: The regulation of endocrinedisrupting chemicals in Europe. Ecol. Soc. 2014, 19, 30. [CrossRef]

25. Wu, L.H.; Zhang, X.M.; Wang, F.; Gao, C.J.; Chen, D.; Palumbo, J.R.; Guo, Y.; Zeng, E.Y. Occurrence of bisphenol S in the environment and implications for human exposure: A short review. Sci. Total Environ. 2018, 615, 87-98. [CrossRef]

26. Thoene, M.; Dzika, E.; Gonkowski, S.; Wojtkiewicz, J. Bisphenol S in Food Causes Hormonal and Obesogenic Effects Comparable to or Worse than Bisphenol A: A Literature Review. Nutrients 2020, 12, 532. [CrossRef]

27. Gallart-Ayala, H.; Moyano, E.; Galceran, M.T. Analysis of bisphenols in soft drinks by on-line solid phase extraction fast liquid chromatography-tandem mass spectrometry. Anal. Chim. Acta 2011, 683, 227-233. [CrossRef] 
28. Becerra, V.; Odermatt, J. Detection and quantification of traces of bisphenol A and bisphenol S in paper samples using analytical pyrolysis-GC/MS. Analyst 2012, 137, 2250-2259. [CrossRef] [PubMed]

29. Viñas, P.; Campillo, N.; Martínez-Castillo, N.; Hernández-Córdoba, M. Comparison of two derivatization-based methods for solid-phase microextraction-gas chromatography-mass spectrometric determination of bisphenol A, bisphenol S and biphenol migrated from food cans. Anal. Bioanal. Chem. 2010, 397, 115-125. [CrossRef]

30. Liao, C.; Kannan, K. Concentrations and profiles of bisphenol A and other bisphenol analogues in foodstuffs from the United States and their implications for human exposure. J. Agric. Food Chem. 2013, 61, 4655-4662. [CrossRef] [PubMed]

31. Cao, X.L.; Zhang, J.; Goodyer, C.G.; Hayward, S.; Cooke, G.M.; Curran, I.H. Bisphenol A in human placental and fetal liver tissues collected from Greater Montreal area (Quebec) during 1998-2008. Chemosphere 2012, 89, 505-511. [CrossRef]

32. Alves, M.G.; Rato, L.; Carvalho, R.A.; Moreira, P.I.; Socorro, S.; Oliveira, P.F. Hormonal control of Sertoli cell metabolism regulates spermatogenesis. Cell. Mol. Life Sci. 2013, 70, 777-793. [CrossRef]

33. Rosenmai, A.K.; Dybdahl, M.; Pedersen, M.; van Vugt-Lussenburg, B.M.A.; Wedebye, E.B.; Taxvig, C.; Vinggaard, A.M. Are structural analogues to bisphenol a safe alternatives? Toxicol. Sci. Off. J. Soc. Toxicol. 2014, 139, 35-47. [CrossRef] [PubMed]

34. Liao, C.; Liu, F.; Alomirah, H.; Loi, V.D.; Mohd, M.A.; Moon, H.B.; Nakata, H.; Kannan, K. Bisphenol S in urine from the United States and seven Asian countries: Occurrence and human exposures. Environ. Sci. Technol. 2012, 46, 6860-6866. [CrossRef]

35. Eladak, S.; Grisin, T.; Moison, D.; Guerquin, M.J.; N’Tumba-Byn, T.; Pozzi-Gaudin, S.; Benachi, A.; Livera, G.; Rouiller-Fabre, V.; Habert, R. A new chapter in the bisphenol A story: Bisphenol S and bisphenol F are not safe alternatives to this compound. Fertil. Steril. 2015, 103, 11-21. [CrossRef] [PubMed]

36. Hecker, M.; Giesy, J.P. Novel trends in endocrine disruptor testing: The H295R Steroidogenesis Assay for identification of inducers and inhibitors of hormone production. Anal. Bioanal. Chem. 2008, 390, 287-291. [CrossRef] [PubMed]

37. Knazicka, Z.; Forgacs, Z.; Lukacova, J.; Roychoudhury, S.; Massanyi, P.; Lukac, N. Endocrine disruptive effects of cadmium on steroidogenesis: Human adrenocortical carcinoma cell line NCI-H295R as a cellular model for reproductive toxicity testing. $J$. Environ. Sci. Health Part A Toxic Hazard. Subst. Environ. Eng. 2015, 50, 348-356. [CrossRef] [PubMed]

38. Gazdar, A.F.; Oie, H.K.; Shackleton, C.H.; Chen, T.R.; Triche, T.J.; Myers, C.E.; Chrousos, G.P.; Brennan, M.F.; Stein, C.A.; La Rocca, R.V. Establishment and characterization of a human adrenocortical carcinoma cell line that expresses multiple pathways of steroid biosynthesis. Cancer Res. 1990, 50, 5488-5496. [PubMed]

39. Rainey, W.E.; Saner, K.; Schimmer, B.P. Adrenocortical cell lines. Mol. Cell. Endocrinol. 2004, 228, 23-38. [CrossRef]

40. Strajhar, P.; Tonoli, D.; Jeanneret, F.; Imhof, R.M.; Malagnino, V.; Patt, M.; Kratschmar, D.V.; Boccard, J.; Rudaz, S.; Odermatt, A. Steroid profiling in H295R cells to identify chemicals potentially disrupting the production of adrenal steroids. Toxicology 2017, 381, 51-63. [CrossRef]

41. OECD. Test No. 456: H295R Steroidogenesis Assay; OECD: Paris, France, 2011. [CrossRef]

42. Mosmann, T. Rapid colorimetric assay for cellular growth and survival: Application to proliferation and cytotoxicity assays. $J$. Immunol. Methods 1983, 65, 55-63. [CrossRef]

43. Schirmer, K.; Chan, A.G.; Greenberg, B.M.; Dixon, D.G.; Bols, N.C. Methodology for demonstrating and measuring the photocytotoxicity of fluoranthene to fish cells in culture. Toxicol. Vitr. Int. J. Publ. Assoc. BIBRA 1997, 11, 107-119. [CrossRef]

44. Yu, P.L.; Lin, H.W.; Wang, S.W.; Wang, P.S. Effects of nonylphenol on the production of progesterone on the rats granulosa cells. J. Cell. Biochem. 2011, 112, 2627-2636. [CrossRef]

45. Desdoits-Lethimonier, C.; Albert, O.; Le Bizec, B.; Perdu, E.; Zalko, D.; Courant, F.; Lesné, L.; Guillé, F.; Dejucq-Rainsford, N.; Jégou, B. Human testis steroidogenesis is inhibited by phthalates. Hum. Reprod. 2012, 27, 1451-1459. [CrossRef]

46. Goldinger, D.M.; Demierre, A.L.; Zoller, O.; Rupp, H.; Reinhard, H.; Magnin, R.; Becker, T.W.; Bourqui-Pittet, M. Endocrine activity of alternatives to BPA found in thermal paper in Switzerland. Regul. Toxicol. Pharmacol. 2015, 71, 453-462. [CrossRef]

47. Lan, H.C.; Wu, K.Y.; Lin, I.W.; Yang, Z.J.; Chang, A.A.; Hu, M.C. Bisphenol A disrupts steroidogenesis and induces a sex hormone imbalance through c-Jun phosphorylation in Leydig cells. Chemosphere 2017, 185, 237-246. [CrossRef]

48. Huang, M.; Liu, S.; Fu, L.; Jiang, X.; Yang, M. Bisphenol A and its analogues bisphenol S, bisphenol F and bisphenol AF induce oxidative stress and biomacromolecular damage in human granulosa KGN cells. Chemosphere 2020, 253, 126707. [CrossRef] [PubMed]

49. Qi, J.; Liu, L.; Yang, J.; Gao, X.; Zhang, W. Bisphenol A decreases progesterone synthesis in human ovarian granulosa cells. Birth Defects Res. 2020, 112, 1843-1849. [CrossRef]

50. Roelofs, M.J.; van den Berg, M.; Bovee, T.F.; Piersma, A.H.; van Duursen, M.B. Structural bisphenol analogues differentially target steroidogenesis in murine MA-10 Leydig cells as well as the glucocorticoid receptor. Toxicology 2015, 329, 10-20. [CrossRef]

51. Pogrmic-Majkic, K.; Samardzija Nenadov, D.; Fa, S.; Stanic, B.; Trninic Pjevic, A.; Andric, N. BPA activates EGFR and ERK1/2 through PPAR $\gamma$ to increase expression of steroidogenic acute regulatory protein in human cumulus granulosa cells. Chemosphere 2019, 229, 60-67. [CrossRef]

52. Amar, S.; Binet, A.; Téteau, O.; Desmarchais, A.; Papillier, P.; Lacroix, M.Z.; Maillard, V.; Guérif, F.; Elis, S. Bisphenol S Impaired Human Granulosa Cell Steroidogenesis in Vitro. Int. J. Mol. Sci. 2020, 21, 1821. [CrossRef] [PubMed]

53. Stocco, D.M.; Wang, X.; Jo, Y.; Manna, P.R. Multiple signaling pathways regulating steroidogenesis and steroidogenic acute regulatory protein expression: More complicated than we thought. Mol. Endocrinol. 2005, 19, 2647-2659. [CrossRef] [PubMed]

54. Chu, P.W.; Yang, Z.J.; Huang, H.H.; Chang, A.A.; Cheng, Y.C.; Wu, G.J.; Lan, H.C. Low-dose bisphenol A activates the ERK signaling pathway and attenuates steroidogenic gene expression in human placental cells. Biol. Reprod. 2018, 98, 250-258. [CrossRef] [PubMed] 